\title{
Rain exclusion affects cambial activity in adult maritime pines
}

\author{
Joana Vieira ${ }^{a, *}$, Cristina Nabais $^{\mathrm{a}}$, Sergio Rossi ${ }^{\mathrm{b}, \mathrm{c}}$, Ana Carvalho ${ }^{\mathrm{a}}$, Helena Freitas ${ }^{\mathrm{a}}$, \\ Filipe Campelo ${ }^{\text {a }}$ \\ ${ }^{a}$ CFE - Centre for Functional Ecology, Department of Life Sciences, University of Coimbra, Calçada Martim de Freitas, 3000-456 Coimbra, Portugal \\ b Département des Sciences Fondamentales, Université du Québec à Chicoutimi, Chicoutimi, Canada \\ ${ }^{\mathrm{c}}$ Key Laboratory of Vegetation Restoration and Management of Degraded Ecosystems, Provincial Key Laboratory of Applied Botany, South China Botanical \\ Garden, Chinese Academy of Sciences, Guangzhou 510650, China
}

\section{A R T I C L E I N F O}

\section{Article history:}

Received 20 May 2016

Received in revised form 9 February 2017

Accepted 19 February 2017

\section{Keywords:}

Climate change experiments

Field experiments

Intra-annual density fluctuations

Pinus pinaster

Plant drought stress

Wood anatomy

\begin{abstract}
A B S T R A C T
Drought frequency and intensity are expected to increase in the Mediterranean basin with unforeseen impacts on forest ecosystems. In this study, we investigated the effect of a rain exclusion experiment on the growth dynamics of adult maritime pine trees. The rain exclusion experiment took place from March to October 2014. Cambial activity and xylem development was weekly monitored in five treated and five control trees during the 2014 growing season. Although growth started simultaneously in all trees, the number of differentiating xylem cells and the rates of cell production were reduced in the rain exclusion trees. Rain exclusion reduced the number and the lumen diameter of latewood tracheids. Cell wall thickness was not affected by the treatment. After the summer, both groups of trees resumed cambial activity, with rain exclusion trees resuming growth two weeks later. The second period of cambial activity observed in autumn, produced earlywood-like tracheids after latewood formation, the so called intraannual density fluctuations (IADF). The position of the IADF within latewood differed between groups, being located within and at the end of latewood in control and rain exclusion trees, respectively. These findings demonstrate that the position of IADFs is determined by the timings of cambial reactivation in autumn.

(c) 2017 Elsevier B.V. All rights reserved.
\end{abstract}

\section{Introduction}

Climate has a strong influence on trees by conditioning their growth and limiting their distribution. Climatic models for the Mediterranean basin predict a reduction in spring precipitation (IPCC, 2013), which can have dramatic consequences for the Mediterranean forest. Dendrochronological analyses taking place in these regions have long established the dependence between radial growth and spring precipitation. Sarris et al. (2007) identified precipitation as the key driver for tree growth in eastern Mediterranean. In western Mediterranean, Campelo et al. (2009, 2007) found a positive correlation between May precipitation and the tree-ring width of Pinus pinea L. and Quercus ilex L. in Portugal. Studies in Spain and Slovenia have also demonstrated the importance of water from the previous winter and current spring in the tree-ring width of Pinus halepensis Mill (Novak et al., 2013).

Although tree rings have a strong climatic signal, relationships between tree-ring width and climate cannot completely explain

\footnotetext{
* Corresponding author.

E-mail address: joana.vieira@uc.pt (J. Vieira).
}

the timings and dynamics of trees responses to climate. In order to further understand the climate-growth relationships, we need to investigate tree-ring formation at higher resolution time scales. Studies on tree xylogenesis may help revealing the climate control of tree growth at weekly to monthly scales, thereby improving our understanding on how climatic conditions are recorded by tree rings (Pacheco et al., 2015). Under Mediterranean climate cambial activity and xylem differentiation can follow a bimodal pattern, with two distinct periods of growth, one in spring when most of the tree-ring is formed and an additional period in autumn if favourable climate conditions occur after the summer (Camarero et al., 2010; Vieira et al., 2015). The cell features of the tracheids differentiated during this second period of growth differ from those previously formed in latewood since their cell wall thickness to lumen diameter ratio is lower than what it is observed in latewood, resembling earlywood (Carvalho et al., 2015; Vieira et al., 2015). These earlywood-like cells are referred to as Intra-Annual Density Fluctuations (IADFs; Battipaglia et al., 2016; Campelo et al., 2007; De Micco et al., 2016).

Latewood IADFs are frequently observed in Mediterranean pines (Campelo et al., 2015; de Luis et al., 2011b; Olano et al., 2012; Rozas et al., 2011; Vieira et al., 2010; Zalloni et al., 2016), and depending 
on its position within latewood the IADF can be classified as type $\mathrm{L}$, when the earlywood-like cells are within latewood, or type $\mathrm{L}^{+}$, when the earlywood-like cells are located between latewood and the earlywood of the following tree-ring (Battipaglia et al., 2016; Campelo et al., 2007). Correlation analysis between the frequency of latewood IADFs and climate has revealed that type $\mathrm{L}$ is triggered by precipitation events in late summer and early autumn, whereas type $\mathrm{L}^{+}$is related to autumn precipitation (Campelo et al., 2007; Vieira et al., 2010, 2009). This suggests that the timing of the triggering factor is responsible for the different types of latewood IADFs. However there are still no xylogenesis studies supporting this hypothesis. The frequency of latewood IADFs has increased in the last decades (Vieira et al., 2010), inciting biologists to identify the climatic drivers of their formation, and to investigate if and how the reduction in precipitation predicted for the Mediterranean basin will affect their frequency.

Experimental designs involving manipulation of precipitation are frequent in saplings (Balducci et al., 2015; de Luis et al., 2011a), but rare in adult trees (Belien et al., 2012; Jyske et al., 2010; Pangle et al., 2012). To our knowledge, manipulation experiments monitoring wood formation and cambial activity on adult trees have never been performed under Mediterranean conditions. The aim of this study is to evaluate how adult maritime pine trees respond to a rain exclusion experiment performed during the growing season. Cambial activity and wood formation were monitored weekly in order to test the hypotheses that rain exclusion (i) reduces the number of cambial and enlargement cells throughout the growing season; (ii) decreases the lumen diameter of tracheids; and (iii) that precipitation events after the end of the rain exclusion trigger the formation of latewood IADFs.

\section{Material and methods}

\subsection{Study site and experimental design}

A rain manipulation experiment was carried out in Perimetro Florestal Dunas de Cantanhede, a maritime pine plantation on sand dunes (Pinus pinaster Ait.) located in the west coast of Portugal $\left(40^{\circ} 21^{\prime} 35.15^{\prime \prime} \mathrm{N}, 8^{\circ} 49^{\prime} 10.06^{\prime \prime} \mathrm{W} ; 15 \mathrm{~m}\right.$ a.s.l). The soil type is podzol, developed from sand and sandstone (Ferreira et al., 2010). The climate is typically Mediterranean with oceanic influence, with precipitation occurring mainly in spring and autumn, interrupted by the summer which is typically hot and dry. The mean annual temperature of the last 30 years was $15.9^{\circ} \mathrm{C}$, and the total annual precipitation was $927 \mathrm{~mm}$. Long-term and daily values of temperature and precipitation were downloaded from the Royal Netherlands Meteorological Institute (http://www.climexp.knmi. $\mathrm{nl} /$ ).

In the same forest stand, two plots of five trees with approximately 50 years, an average of $15 \mathrm{~m}$ of height and $32 \mathrm{~cm}$ of diameter at breast height were selected and divided into control and rain exclusion trees. In each plot, trees were located within a $100 \mathrm{~m}^{2}$ area in order to ensure that each group of trees was subjected to similar environmental conditions. The below canopy precipitation exclusion was fulfilled by installing a continuous plastic sheet on the forest floor covering approximately twice the area of the tree's canopy. Maritime pines have a deep taproot with well-developed secondary roots (Pereira, 2002), with the main root system located directly below the canopy. The exclusion plot was located on a slope and surrounded by a ditch which diverted the rain water away from the plot (Fig. 1). The plastic sheet was installed on February 28th (DOY 59) and removed on October 1st (DOY 274) of 2014, after removing the upper layer of organic matter (needles and moss), which was afterwards replaced over the plastic sheet in order to

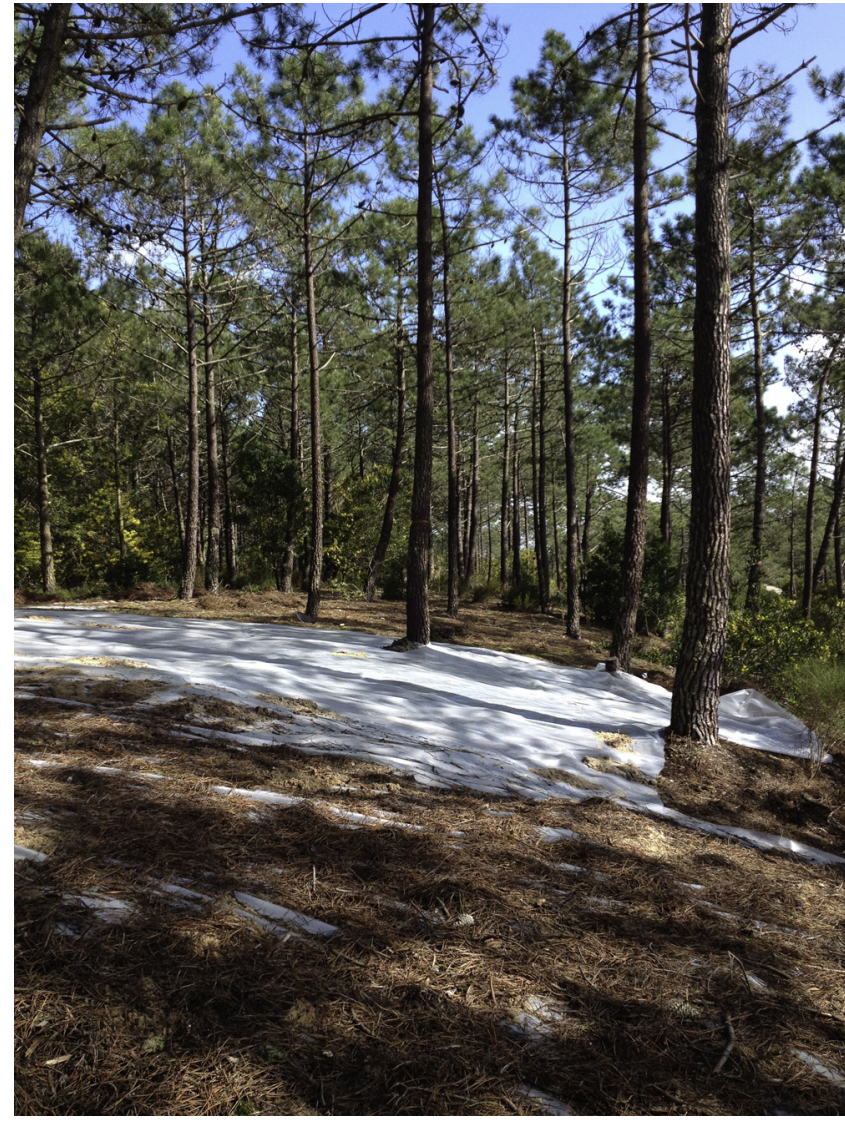

Fig. 1. Installation of the plastic sheet in the rain exclusion plot.

dissimulate it and decrease the effect of the plastic on soil temperature.

A soil moisture probe PR2 from Delta-T-Devices was installed in the control plot in January 2014 and programed to record soil moisture values every $30 \mathrm{~min}$ at a depth of $100 \mathrm{~cm}$. Data were stored in a DL2e data logger also from Delta-T-Devices. Since only one soil moisture probe was available, readings in the rain exclusion plot were not continuous.

\subsection{Xylem development}

Sampling of the cambium and developing xylem was carried out from March 2014 (DOY 62) to March 2015 (DOY 68) by weekly collection of microcores on the stem using a Trephor (Rossi et al., 2006). The microcores were collected $45 \mathrm{~cm}$ below and above breast height in a spiral pattern on the south-facing side of the stem to minimize the growth variability around the stem (Lupi et al., 2014). Microcores were collected approximately $5 \mathrm{~cm}$ apart between each sampling date to prevent getting resin ducts from previous sampling points. After collection, the microcores were placed in eppendorfs filled with alcohol ( $50 \%$ in water) and stored at $5{ }^{\circ} \mathrm{C}$ to avoid tissue deterioration. The microcores were then dehydrated through successive immersions in alcohol and D-limonene and embedded in paraffin (Rossi et al., 2006). Transverse sections 6-10 $\mu \mathrm{m}$ thick were cut from the samples with a rotary microtome, stained with cresyl violet acetate $(0.17 \%$ in water $)$, and immediately observed with a microscope (400-500 x magnification) under visible and polarized light to distinguish between the different xylem differentiation phases. Cambial and enlarging cells only present primary cell walls thus do not shine under polarized light, being easily distinguished from the cells depositing secondary cell wall and mature cells. Enlarging cells are distinguished from cambial 


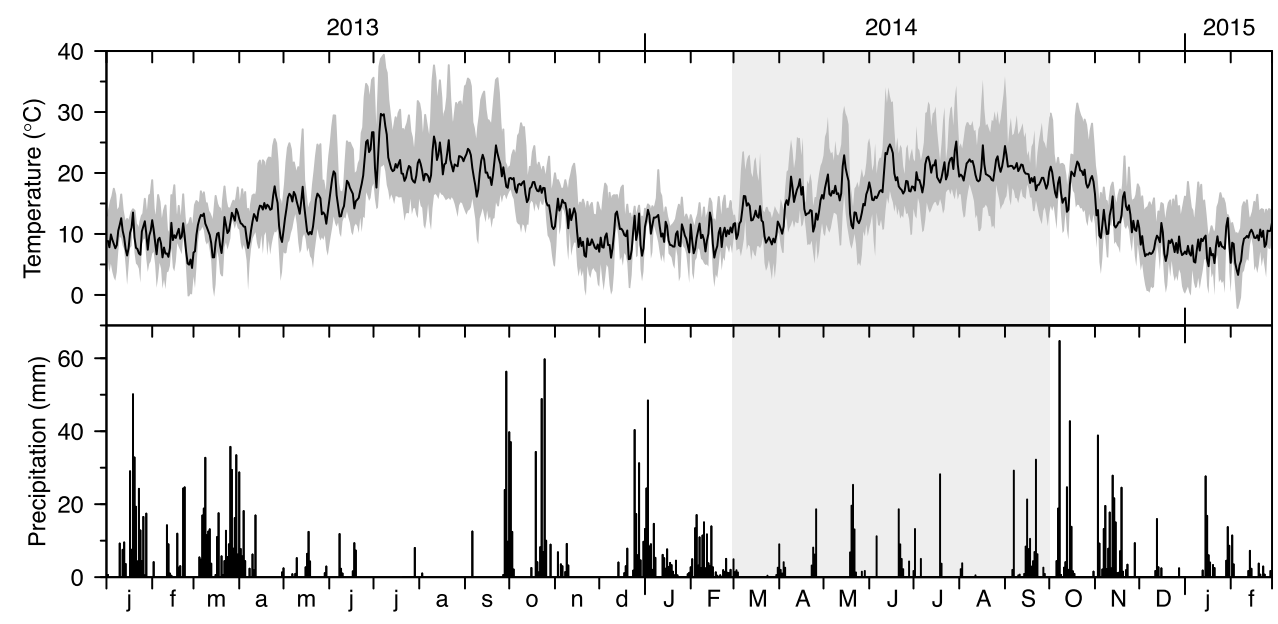

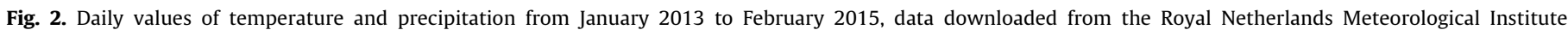

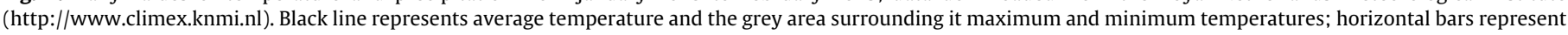
precipitation; and the light grey area the exclusion period.

cells since they present a diameter at least twice that of a cambial cell. Wall thickening cells shine under polarized light and show a light violet coloration changing to dark violet at the end of maturation. When lignification is complete the entire cell wall presents a blue coloration and tracheids reach maturation (Gričar et al., 2005). The number of cambial and developing xylem cells was counted along three radial rows for each sampling date.

\subsection{Tracheid features}

In March 2015 (DOY 68), after the end of the 2014 growing season an extra microcore was collected and processed as described above. The resulting sections were stained with $1 \%$ aqueous safranin and permanently fixed using Canada balsam (Eukitt). The tree rings produced in 2013 and 2014 were photographed using a camera fixed on a microscope (Leica, model DCF295), at 20x magnification. The 2013 tree ring was used to determine tracheid features before the treatment in order to assure that the differences observed in 2014 were due to the rain exclusion and not the trees. Images were processed using ImageJ (http://rsbweb.nih.gov/ $\mathrm{ij} /$ ), where three radial rows were selected to measure the radial lumen diameter and cell wall thickness of each tracheid.

The tree rings of 2013 and 2014 were also analysed to determine whether intra-annual density fluctuations (IADFs) were formed in latewood. The latewood tracheids forming an IADF are anatomically defined by presenting a lumen diameter wider than twice the cell wall thickness (Vieira et al., 2015), which according to the Mork's definition corresponds to earlywood (Denne, 1988).

\subsection{Statistical analysis}

The number of cambial, enlarging, cell-wall thickening and mature cells throughout the growing season was fitted with generalized additive mixed models (GAMMs) in order to compare the effect of rain exclusion in cambial activity and cell differentiation. Several models were considered and the best fitting model was selected based on the Akaike Information Criterion (Table S1; AIC; Akaike, 1973). To account for auto-correlation in the data, tree identity was treated as a random effect. Models were performed using the $m g c v$ package (Wood, 2006) in the R computing environment ( $R$ Development Core Team, 2009). The following GAMM was applied:

$y=\alpha+s(x):$ treat $+\beta \times x+\varepsilon$ where $y$ is the number of cells; $x$ is the DOY; $s$ is a smooth function; the colon (:) between the two terms indicates an interaction between those terms; treat is the treatment, which is a dummy variable ( 0 , control; 1 , exclusion); $\alpha$ is the intercept, $\beta$ accounts for the variance component (random effect) for tree and $\varepsilon$ is the error term. Differences between control and rain exclusion trees were considered significant when the point-wise confidence intervals of the fitted curves did not overlap (Table S2).

Tracheid features were standardized to its relative position within the tree ring so that the lumen diameter and cell wall thickness could be compared between control and rain exclusion trees in 2013 and 2014 (Campelo et al., 2016). This method determines the relative position of all tracheids by dividing the distance between the beginning of the ring and the center of each tracheid by the total ring width and then multiplies it by 100 (Campelo et al., 2016). By standardizing the tracheidograms to the relative position of the tracheids the effect of the number of tracheids was eliminated which allowed comparing just the anatomical characteristics (Campelo et al., 2016). The standardization was performed using the method relPos from the package tracheideR in the $\mathrm{R}$ computing environment (Campelo et al., 2016). The tracheidograms were also fitted with GAMMs, in order to compare the effect of rain exclusion on tracheid features. The procedure used for xylogenesis data was followed for the tracheidogram analysis. Several models with increasing complexity were considered and the best fitting model was selected using the AIC (Table S3). The following GAMM was selected:

$y=\alpha+s(x):$ treat_year $+\beta \times x+\varepsilon$

where $y$ is the tracheid feature (LD or CWT), $\alpha$ is the intercept, $x$ is the relative position of the tracheid feature within the tree-ring, $s$ is a smooth function, the colon (:) between the two terms indicates an interaction between those terms, treat_year is the interaction between treatment and year, $\beta$ accounts for the variance component (random effect) for tree and $\varepsilon$ is the error term. Differences between control and rain exclusion trees were considered significant when the point-wise confidence intervals of the fitted curves did not overlap (Table S4).

Differences in tracheid features (number, lumen diameter and cell wall thickness) were tested with generalized linear mixed models (GLMMs) with treatment and time as fixed factors and tree identity as random factor, using the lme function from the nlme package (Pinheiro et al., 2016). Coefficients were estimated using restricted maximum likelihood methodology (REML), and relationships were considered significant when $P<0.05$. 


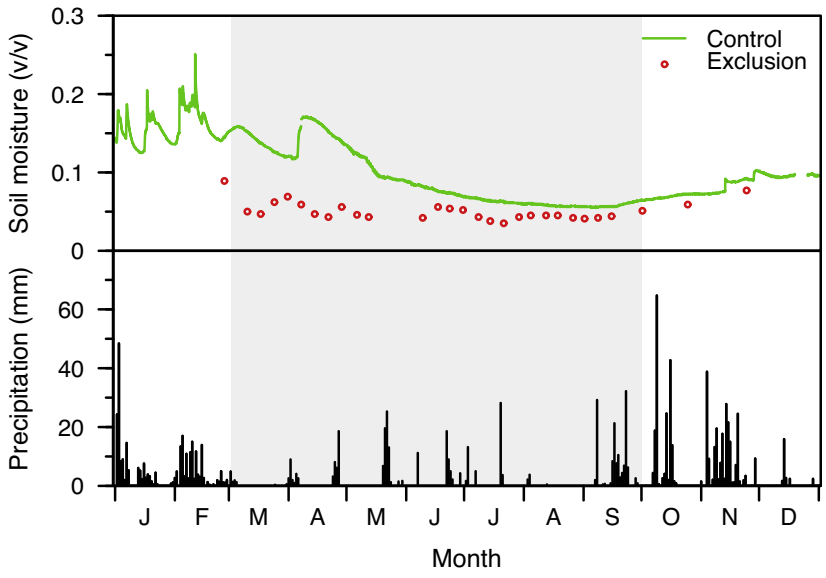

Fig. 3. Soil moisture (V/V) in the control (solid green line) and rain exclusion (red dots) plots measured at $100 \mathrm{~cm}$ depth during the 2014 growing season and daily precipitation for the same period (data downloaded from the Royal Netherlands Meteorological Institute, http://www.climex.knmi.nl).(For interpretation of the references to colour in this figure legend, the reader is referred to the web version of this article.)

\section{Results}

\subsection{Weather conditions in the study period}

The mean variation in temperature registered in 2013 was similar to the one observed in the long-term mean. In 2014, however the spring was $3^{\circ} \mathrm{C}$ warmer than the long-term mean spring temperature $\left(14.6^{\circ} \mathrm{C}\right)$ and the summer $2^{\circ} \mathrm{C}$ colder $\left(22^{\circ} \mathrm{C}\right)$. Winter temperatures were similar between study years, with both years presenting a mean temperature of $10^{\circ} \mathrm{C}$ (Fig. 2). In spring mean temperatures were of 14.0 and $15.6^{\circ} \mathrm{C}$ in 2013 and 2014, respectively. Mean summer temperatures were similar, with means of 21.8 and $20.2^{\circ} \mathrm{C}$ in 2013 and 2014 . However, the mean maximum temperature in $2013\left(28.7^{\circ} \mathrm{C}\right)$ was almost $2^{\circ} \mathrm{C}$ warmer than in 2014 $\left(26.9^{\circ} \mathrm{C}\right)$. In fall, the mean temperatures were of 13.5 and $14.2^{\circ} \mathrm{C}$ in 2013 and 2014, respectively.

Total precipitation was $1400 \mathrm{~mm}$ in 2013 and $1220 \mathrm{~mm}$ in 2014 (Fig. 2), both years with precipitation above the long term mean $(927 \mathrm{~mm})$. Regarding the precipitation regime differences were observed in spring with a total of $447 \mathrm{~mm}$ observed in 2014 and $137 \mathrm{~mm}$ in 2013, versus the $231 \mathrm{~mm}$ registered for the same period in the last 30 years. Summer was also wetter in $2014(109 \mathrm{~mm})$ than in $2013(42 \mathrm{~mm})$. Differences in the amount of precipitation were also observed in fall, with a total of $405 \mathrm{~mm}$ in 2013 and $547 \mathrm{~mm}$ in 2014 , both years registering higher amounts of precipitation than the long-term mean ( $315 \mathrm{~mm})$.

The soil moisture in the control plot presented the highest value in February ( $0.25 \mathrm{v} / \mathrm{v}$ ) slowly decreasing afterwards (Fig. 3). The first available value of soil moisture from the exclusion plot (DOY 55) was slightly lower $(0.1 \mathrm{v} / \mathrm{v})$ than in the control plot $(0.15 \mathrm{v} / \mathrm{v})$. During the rain exclusion period, soil moisture was always lower in the rain exclusion plot than in the control plot. After removing the plastic sheet the soil moisture started to increase and by December the values were similar in both plots.

\subsection{Xylem development and GAMMs}

The use of GAMMs allowed comparing the number of cambial and differentiating xylem cells between control and rain exclusion trees while removing the random effect of tree identity (Fig. 4; Table S2). Cambial and xylem differentiation zones exhibited a clear variation in the number of cells throughout the year, which represented the annual pattern of cambial activity (Fig. 4). At the start of sampling there were on average of $6.5 \pm 2$ cambial cells and $2 \pm 1$ enlarging cells suggesting that the cambium was already active in March (DOY 62) in all trees. The annual variation in the number of cambial cells was similar between control and rain exclusion for the entire study period (Fig. 4). The maximum number of cells was observed between mid-March and May $(7 \pm 1)$, time after which cambium cells presented a constant number of approximately 6 cells until August, slowly decreasing afterwards. In October the number of cambial cells increases again until mid-November. The minimum number of cells was observed in the cambial zone in December and January 2015 (5 \pm 1 ). In February it began to increase again in both groups, indicating a resumption of cambial activity.

In the first sampling date (DOY 62), there were already cells in enlargement in all trees. The number of enlarging cells was higher in control trees from August to September. Both groups of trees presented a maximum of enlarging cells in April, followed by a decrease until August in control trees, and until September in the rain exclusion trees. In September and October, there was a second period of cell enlargement in control and rain exclusion trees, respectively. The enlargement phase ended in November(DOY 300) in the control trees and two weeks later in the rain exclusion plot (DOY 314).

Cell wall deposition stage started one week earlier in the rain exclusion (DOY 76) than in the control plot. The variation in the number of cells in wall deposition was similar between groups of trees, except for the period from mid-August to December when control trees presented a higher number of cells than rain exclusion trees (Fig. 4). Control trees presented the first maximum of lignifying cells between May and July, with approximately 7 cells, and a second one in October-November during which there were up to 10 cells in lignification. Regarding the rain exclusion trees, the first maximum was observed between April and July, with an average of 8 cells, and a second one in November-December with an average of 6 cells in lignification. The cell wall deposition phase ended in both groups of trees in March 2015 (DOY $365+61$ ).

The first mature cells were observed in mid-April (DOY 111) in all trees. The increment of these cells was similar between the two groups until the end of September (DOY 265). In October control trees exhibited a higher number of mature tracheids than rain exclusion trees. By the end of the growing season control trees had differentiated 42 tracheids and rain exclusion Trees 35 (Fig. 4).

\subsection{Intra-annual density fluctuations}

Latewood IADFs were observed in both groups of trees and in both years (Fig. 5). In 2013 there were IADFs in 3 out of 5 control trees and in 5 out of 5 rain exclusion trees. In 2014 there were 2 trees that formed IADFs in the control group and 4 in the rain exclusion group. Two types of IADFs could be found on latewood: IADF type L characterized by earlywood-like cells within latewood, and IADF type $\mathrm{L}^{+}$with earlywood-like cells between latewood and the earlywood of the following tree ring (Fig. 5). The types of IADFs formed differed between years and experiment. Although in 2013 IADFs type $\mathrm{L}$ and $\mathrm{L}+$ were present in both control and rain exclusion trees, in 2014 control trees presented only IADFs type $L$ and rain exclusion trees only IADFs type $\mathrm{L}^{+}$.

\subsection{Tracheid features}

Regarding the tracheid features between years and treatment (Fig. 6, Table 1), lumen diameter of earlywood tracheids decreased $2 \mu \mathrm{m}$ in both groups of trees from 2013 to 2014, presenting an average of 36 and $32 \mu \mathrm{m}$ in 2013 in control and rain exclusion trees, respectively (Fig. 6). The average lumen diameter of latewood tracheids of control trees was $13 \mu \mathrm{m}$ in 2013, presenting a small increase in 2014. On the contrary, the lumen diameter of exclusion 


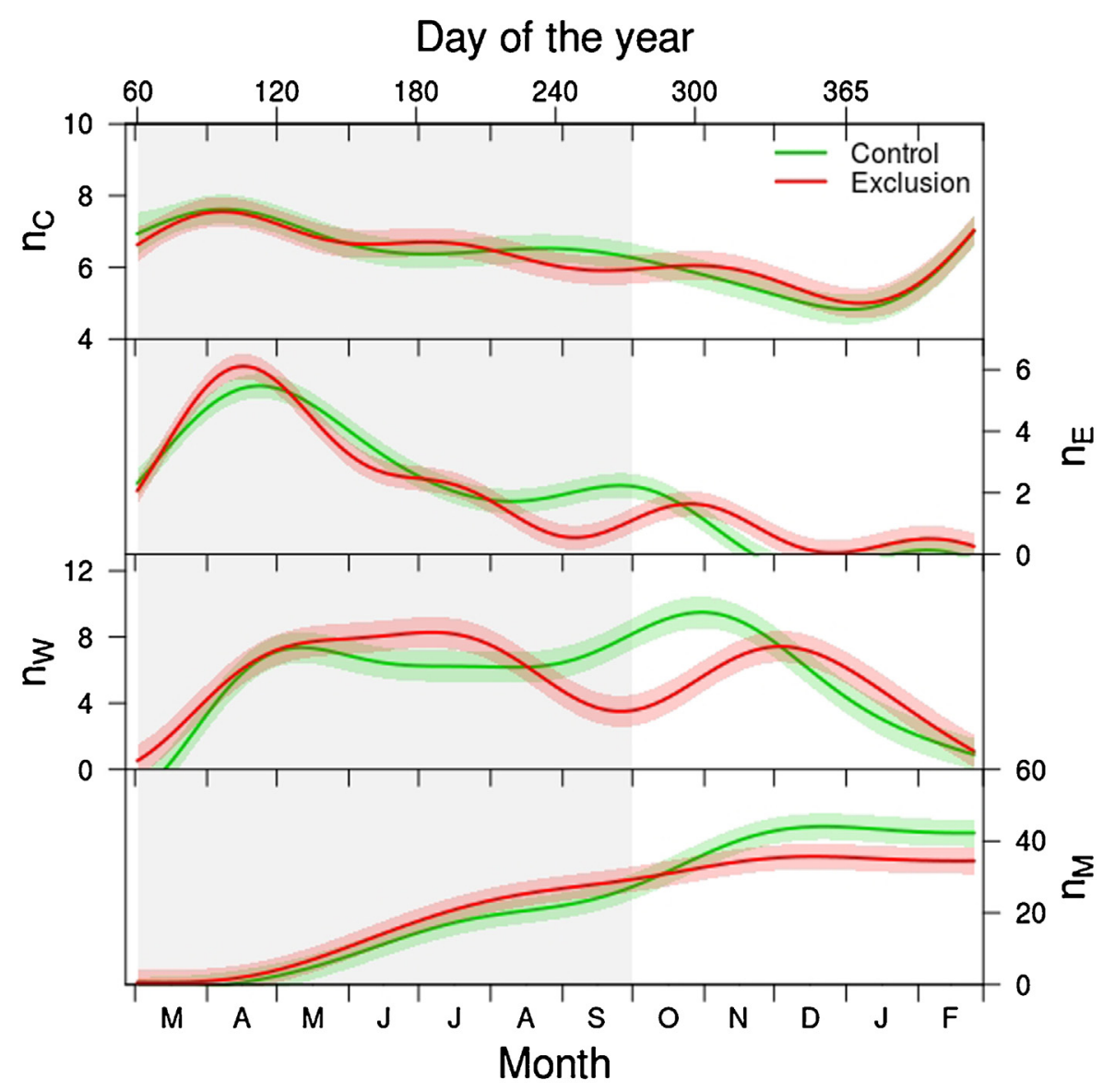

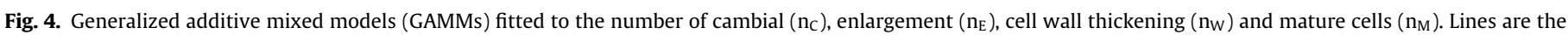

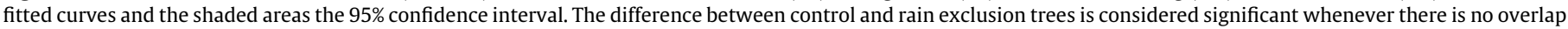
between the curves and confidence interval area. Shadow light grey area represents the rain exclusion period.

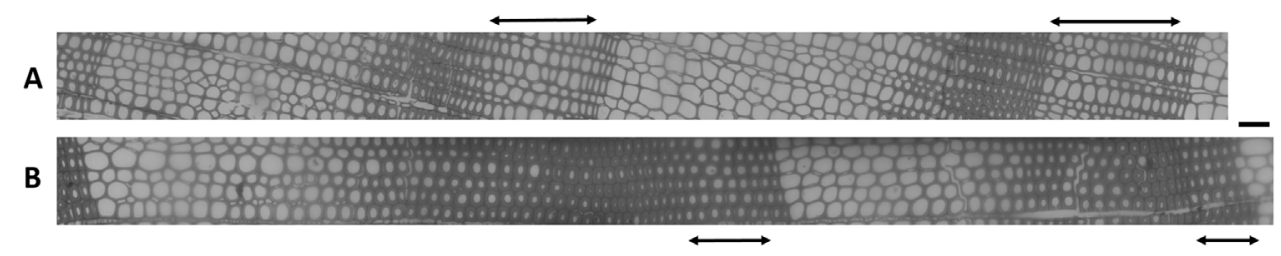

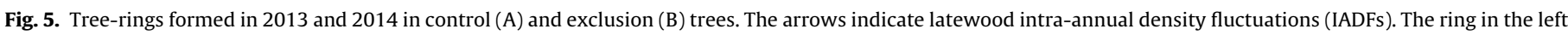
side of the image corresponds to the year 2013. In 2014 control trees produced an IADF type L and rain exclusion trees a type $\mathrm{L}^{+}$. Scale represents $100 \mu \mathrm{m}$.

Table 1

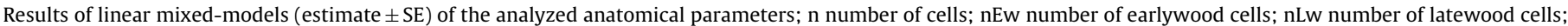

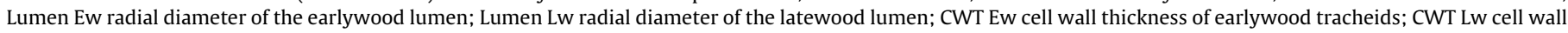
thickness of latewood tracheids. Significant values are in bold. $\left({ }^{*} P<0.05 ;{ }^{* *} P<0.01 ;{ }^{* * *} P<0.001\right)$.

\begin{tabular}{|c|c|c|c|c|c|c|c|}
\hline & $\mathrm{n}$ & nEw & nLw & Lumen Ew & Lumen Lw & CWT EW & CWT Lw \\
\hline Intercept & $36.27 \pm 10.10^{* *}$ & $18.40 \pm 5.58^{*}$ & $17.87 \pm 5.16^{* *}$ & $36.37 \pm 2.31^{* * *}$ & $12.7 \pm 1.34^{* * *}$ & $5.28 \pm 0.26^{* * *}$ & $7.29 \pm 0.57^{* * *}$ \\
\hline Year $(2014)$ & $6.67 \pm 4.86$ & $3.13 \pm 2.68$ & $3.53 \pm 3.76$ & $-1.80 \pm 2.48$ & $0.95 \pm 1.46$ & $-0.18 \pm 0.21$ & $-0.54 \pm 0.49$ \\
\hline Treatment (exclusion) & $27.13 \pm 14.29$ & $10.47 \pm 7.88$ & $16.67 \pm 7.30$ & $-4.28 \pm 3.27$ & $0.28 \pm 1.89$ & $0.06 \pm 0.37$ & $0.14 \pm 0.81$ \\
\hline Year $\times$ Treatment & $24.00 \pm 6.87^{* *}$ & $-7.20 \pm 3.78$ & $-16.80 \pm 5.32^{*}$ & $0.70 \pm 3.51$ & $-4.76 \pm 2.06^{*}$ & $0.10 \pm 0.29$ & $0.51 \pm 0.70$ \\
\hline \multicolumn{8}{|l|}{ Random effect ${ }^{1}$} \\
\hline Tree & 21.24 & 11.73 & 9.89 & 3.36 & 1.9 & 0.49 & 0.02 \\
\hline
\end{tabular}

1 Standard deviation.

trees decreased from $12 \mu \mathrm{m}$ to $9 \mu \mathrm{m}$ from 2013 to 2014 . Cell wall presented an average thickness of $5 \mu \mathrm{m}$ in earlywood and $7 \mu \mathrm{m}$ in latewood tracheids, in both years and treatments.

When comparing the tracheid features in the GLMMs analysis only the interaction between treatment and year presented significant differences (Table 1). Thus, the total number of tracheids, the number of latewood tracheids and its lumen area decreased in response to the rain exclusion experiment (Fig. 6).

The standardization of tracheidograms allowed the comparison of lumen diameter and cell wall thickness along the tree rings of control and rain exclusion trees (Fig. 7; Table S4). This analysis showed that there were no significant differences in the LD 


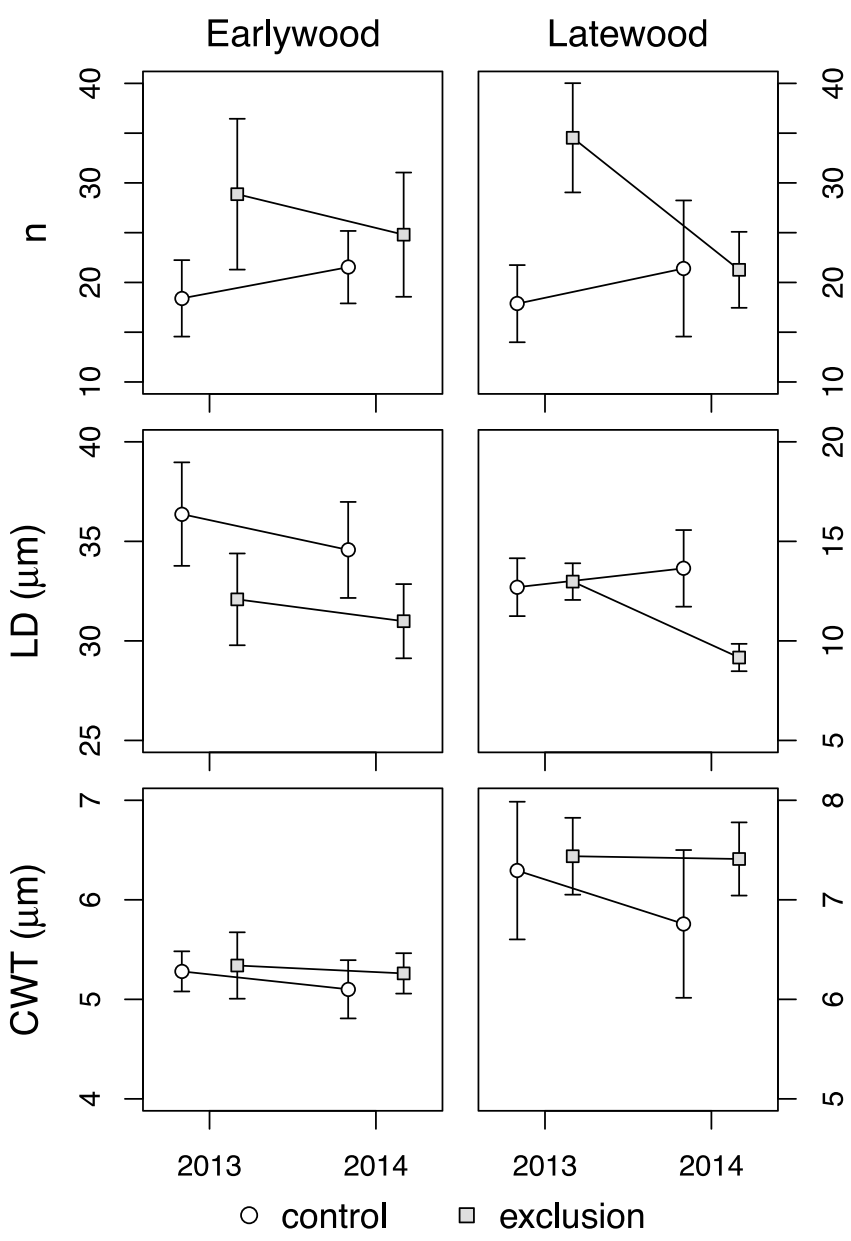

Fig. 6. Number of earlywood and latewood tracheids ( $n$ ), lumen diameter $(L D)$ and cell wall thickness (CWT) observed in the control (open circle) and exclusion trees (grey) in the 2013 and 2014. Bars represent standard error.

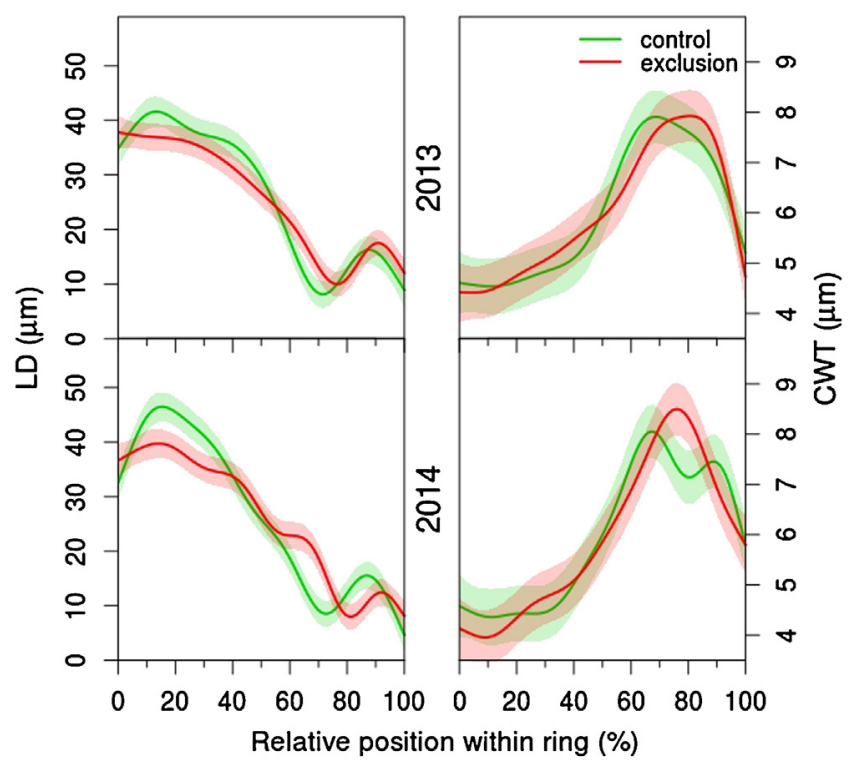

Fig. 7. Generalized additive mixed models (GAMMs) fitted to the lumen diameter and cell wall thickness tracheidograms standardized to the relative position of the tracheids within the tree ring. Lumen diameter (LD) and cell wall thickness (CWT) in the control (green line) and exclusion trees (red line). Solid line represents the average and the shaded areas the $95 \%$ confidence interval. (For interpretation of the references to colour in this figure legend, the reader is referred to the web version of this article.) and CWT between control and rain exclusion trees in 2013. In the experimental year there were differences between control and rain exclusion trees in the last $40 \%$ of the tree-ring. The increase in LD observed in the last 30\% of the tree ring in both years and groups of trees represented a latewood IADF. However, in 2014 the second LD increment was observed at $85 \%$ of the tree-ring in control trees and at $95 \%$ in exclusion trees, corresponding to IADF type $\mathrm{L}$ and $\mathrm{L}^{+}$respectively. Regarding cell wall thickness, there were no differences between control and rain exclusion trees in both years.

\section{Discussion}

This study presents the results of cambial activity and wood formation in mature maritime pine trees subjected to rain exclusion. Cambial activity had already started at the beginning of the sampling season in all study trees, however rain exclusion trees presented less differentiating xylem cells during most of the growing season, resulting in a narrower tree ring. The anatomical characteristics of tracheids, namely the lumen diameter and cell wall thickness, were also compared between treatments during the study year and the year before. The latewood tracheids of trees exposed to rain exclusion presented a narrower lumen than control trees, whereas the cell wall thickness did not show differences between rain exclusion and control trees.

\subsection{Cambial activity and wood formation}

Wood formation is defined by the timings of cambial activity and rates of cell division, with longer periods of cambial activity and higher rates of cell division resulting in wider tree rings (Lupi et al., 2010; Rossi et al., 2012). Our findings showed that the onset of cambial divisions and xylem differentiation had already started at the beginning of the sampling season. Although enlargement ended later in the rain exclusion trees, a higher number of differentiating tracheids was observed during most of the growing season in control trees, indicating a higher rate of cell production in those trees. Water availability affects turgor pressure which plays a crucial role in the processes of cell division and enlargement (Kutschera and Niklas, 2013; Steppe et al., 2015). Cell expansion depends on turgor pressure since a threshold turgor needs to be achieved in order for the necessary structural changes in the cell wall to occur, allowing the cell to enlarge. Rain exclusion trees presented less enlarging cells than control tress probably because of the lower turgor pressure available for the cambial cells to undergo enlargement. These results are in agreement with a previous study made in this site where it was observed that differences in the increment rates between similar trees were due to the rate of cell division rather than the timings of xylogenesis (Vieira et al., 2014). Likewise, Cuny et al. (2014) demonstrated that approximately $75 \%$ of the growth variation could be explained by the rate of cell production.

\subsection{Tracheid anatomy}

The rain exclusion produced differences not only in the dynamics of xylem formation but also in the number and anatomy of the tracheids. Rain exclusion trees presented less tracheids and narrower lumen diameter on latewood when compared to the previous year, while the control group showed a slight increase. During enlargement, the pressure applied by the vacuole water on the primary wall determines the final size of the cell (Kutschera and Niklas, 2013). If less water is available, the tracheids formed will present a smaller lumen area. Lumen area has a strong impact on the physiology of trees, since small changes in it can significantly increase or reduce the conductivity area according to the Hagen-Poisseuille's law (Hacke et al., 2001; Pittermann et al., 2006). The number of tracheids has also an impact in conductivity. The reduction in the 
number of tracheids in the rain-exclusion trees could be due to the direct effect of turgor pressure on the cell division rate or to the effect of water stress on stomata closure. Maritime pine is considered an isohydric species that prevents xylem cavitation by stomata closure (Loustau et al., 1996). By closing the stomata, the carbon available for secondary growth decreases, resulting in a lower tracheid production (Oribe et al., 2003).

Decreasing the number and size of tracheids is a common response to periods of water shortage. Belien et al. (2012) and Jyske et al. (2010) observed a reduction in the lumen area of tracheids of Picea mariana (Mill.) Britton, Stearns \& Toggenburg and Picea abies (L.) Krast., respectively, when subjected to experimental drought treatments. In contrast, Eilmann et al. (2011) found that drought conditions induced an increase in the lumen area of Pinus sylvestris L. tracheids, however a shorter growing season was also observed which could help counterbalancing the risk of cavitation. The divergent response to drought represents a different strategy and adaptation of the species. On one hand, trees avoid cavitation by decreasing the conductive area, which in turn decreases transpiration rates and carbon uptake. But on the other hand, trees can increase their conductive system, making it more efficient but also more prone to cavitation. Both strategies carry risks for trees and if there is a recurrent or prolonged drought it can ultimately result in tree death either by carbon starvation or hydraulic failure (Choat et al., 2012; Martínez-Vilalta et al., 2012; McDowell and Allen, 2015).

Cell wall thickness presented little variation between treatments and years confirming previous studies where it was observed that the adjustments in xylem anatomy occurred mainly by changing the lumen diameter in response to environmental conditions (Carvalho et al., 2015; Cuny et al., 2014). For example, in a study comparing tracheidograms of four consecutive years in maritime pine Carvalho et al. (2015) showed that the anatomical variation between rings was observed in the lumen diameter and not in cellwall thickness. Similarly, Cuny et al. (2014) found that the amount of material deposited in the cell wall remained constant along the tree ring.

\subsection{Intra-annual density fluctuation}

A resumption of cambial activity and cell differentiation was observed in rain exclusion and control trees in fall, however there was a delay between control and rain exclusion trees which resulted in the formation of different types of latewood IADFs (Battipaglia et al., 2016; Campelo et al., 2007; Vieira et al., 2015). Latewood IADFs are triggered by a combination of a dry summer followed by a wet early autumn (Campelo et al., 2013; Carvalho et al., 2015) and their formation or not is highly dependent on the timing of the precipitation events after the summer drought (Vieira et al., 2015). Additionally, dendrochronological studies found that the position of the latewood IADFs were also dependent on the timing when the triggering factor occurred during the growing season (Campelo et al., 2007; Vieira et al., 2009). Although present in both groups of trees, the latewood IADF formed in rain exclusion and control trees was different, with control trees presenting a type $\mathrm{L}$ and rain exclusion trees a type $\mathrm{L}^{+}$. Control trees presented a second period of xylem differentiation in September and rain exclusion trees one month later. Based on our results, we can conclude that the relative position of the IADF inside the latewood is determined by the timing of the second period of enlargement. The formation of two types of IADFs in latewood in 2014 is thus a direct consequence of the rain exclusion treatment. The second period of xylem differentiation also illustrates the capacity of maritime pine to resume wood formation after a prolonged period of rain exclusion, reinforc- ing the highly plastic trait of this species and the close adaptation to the variability of the Mediterranean climate.

\subsection{Tracheidograms}

The results of the standardized tracheidograms are in agreement with the anatomical observations of IADF formation, showing that control and rain exclusion trees formed different types of IADFs. By standardizing the tracheidograms to the relative position of the tracheids within the ring it is possible to compare the intraring variation of tracheid features among different rings (Campelo et al., 2016). The tracheidograms revealed differences in the cell wall thickness in the experimental year, revealing that control trees presented thinner cell walls in latewood. This was observed in the portion of the ring where the IADF was formed. As pointed out by Cuny et al. (2014), the amount of material deposited in the cell walls is nearly constant within the ring and it is the area of the tracheid that adjusts. Thus, the same amount of cell wall material deposited on wider tracheids should result in thinner cell walls.

\section{Conclusions}

The rain exclusion experiment reduced the number of tracheids and induced the production of latewood tracheids with narrower lumen diameter, demonstrating the importance of water during the process of cell differentiation. Xylogenesis had already started when the sampling began on both tree groups, however a higher number of differentiating tracheids were observed in control trees throughout the growing season. Rain exclusion decreased the rate of cell production and also the differentiation rate since the number of cambial cells was always higher in these trees. The second period of xylem differentiation was delayed in the rain exclusion trees, resulting in the formation of an IADF type $\mathrm{L}^{+}$, whereas in control trees an $\mathrm{L}$ type was formed. It is the first time that the ontogenesis of $\mathrm{L}$ and $\mathrm{L}^{+}$IADFs is observed and that it can be related to the different timings of cell enlargement observed in the second period of xylem differentiation. Our results demonstrated the resistance of maritime pine to a prolonged period of rain exclusion and the ability of trees to resume cambial activity and differentiation in response to precipitation.

\section{Acknowledgments}

This study was supported by the Fundação para a Ciência e a Tecnologia, Ministério da Educação e Ciência (FCT) co-financed by Compete, through the project EXPL/AAG-GLO/1885/2013. Filipe Campelo (SFRH/BPD/111307/2015) and Joana Vieira (SFRH/BPD/105656/2015) were supported by postdoctoral research grants from FCT with funds from POPH (Portuguese Operational Human Potential Program), QREN Portugal (Portuguese National Strategic Reference Framework) and FSE (European Social Fund). The authors would like to thank the Associate Editor, Nathaniel Brunsell and to two anonymous reviewers for helpful comments and suggestions on an earlier version of the manuscript.

\section{Appendix A. Supplementary data}

Supplementary data associated with this article can be found, in the online version, at http://dx.doi.org/10.1016/j.agrformet.2017. 02.024 .

\section{References}

Akaike, H., 1973. Information theory and an extension of the maximum likelihood principle. In: Petran, B., Csaaki, F. (Eds.), International Symposium on Information Theory. Akadeemiai Kiadi, Budapest, Hungry, pp. 267-281. 
Balducci, L., Deslauriers, A., Giovannelli, A., Beaulieu, M., Delzon, S., Rossi, S. Rathgeber, C.B.K., 2015. How do drought and warming influence survival and wood traits of Picea mariana saplings? J. Exp. Bot. 66, 377-389, http://dx.doi. org/10.1093/jxb/eru431.

Battipaglia, G., Campelo, F., Vieira, J., Grabner, M., De Micco, V., Nabais, C., Cherubini, P., Carrer, M., Bräuning, A., Cufar, K., Di Filippo, A., García-González, I., Koprowski, M., Klisz, M., Kirdyanov, A.V., Zafirov, N., de Luis, M., 2016. Structure and function of intra-annual density fluctuations: mind the gaps. Front. Plant Sci. 7 (595), http://dx.doi.org/10.3389/fpls.2016.00595.

Belien, E., Rossi, S., Morin, H., Deslauriers, A., 2012. Xylogenesis in black spruce subjected to rain exclusion in the field. Can. J. For. Res. 42, 1306-1315, http:// dx.doi.org/10.1139/X2012-095.

Camarero, J.J., Olano, J.M., Parras, A., 2010. Plastic bimodal xylogenesis in conifers from continental Mediterranean climates. New Phytol. 185, 471-480, http:// dx.doi.org/10.1111/j.1469-8137.2009.03073.x.

Campelo, F., Nabais, C., Freitas, H., Gutierrez, E., 2007. Climatic significance of tree-ring width and intra-annual density fluctuations in Pinus pinea from a dry Mediterranean area in Portugal. Ann. For. Sci. 64, 229-238, http://dx.doi.org/ 10.1051 /forest.

Campelo, F., Nabais, C., García-González, I., Cherubini, P., Gutiérrez, E., Freitas, H., 2009. Dendrochronology of Quercus ilex L. and its potential use for climate reconstruction in the Mediterranean region. Can. J. For. Res. 39, 2486-2493, http://dx.doi.org/10.1139/X09-163.

Campelo, F., Vieira, J., Nabais, C., 2013. Tree-ring growth and intra-annual density fluctuations of Pinus pinaster responses to climate: does size matter? Trees Struct. Funct. 27, 763-772, http://dx.doi.org/10.1007/s00468-012-0831-3.

Campelo, F., Vieira, J., Battipaglia, G., de Luis, M., Nabais, C., Freitas, H., Cherubini, P., 2015. Which matters most for the formation of intra-annual density fluctuations in Pinus pinaster: age or size? Trees - Struct. Funct. 29, 237-245, http://dx.doi.org/10.1007/s00468-014-1108-9.

Campelo, F., Nabais, C., Carvalho, A., Vieira, J., 2016. tracheideR-An R package to standardize tracheidograms. Dendrochronologia 37, 64-68, http://dx.doi.org/ 10.1016/j.dendro.2015.12.006.

Carvalho, A., Nabais, C., Vieira, J., Rossi, S., Campelo, F., 2015. Plastic response of tracheids in Pinus pinaster in a water-limited environment: adjusting lumen size instead of wall thickness. PLoS One 10, 1-14, http://dx.doi.org/10.1371/ journal.pone.0136305.

Choat, B., Jansen, S., Brodribb, T.J., Cochard, H., Delzon, S., Bhaskar, R., Bucci, S.J., Feild, T.S., Gleason, S.M., Hacke, U.G., Jacobsen, A.L., Lens, F., Maherali, H., Martínez-Vilalta, J., Mayr, S., Mencuccini, M., Mitchell, P.J., Nardini, A., Pittermann, J., Pratt, R.B., Sperry, J.S., Westoby, M., Wright, I.J., Zanne, A.E., 2012. Global convergence in the vulnerability of forests to drought. Nature 491, 752-755, http://dx.doi.org/10.1038/nature11688.

Cuny, H.E., Rathgeber, C.B.K., Frank, D., Fonti, P., Fournier, M., 2014. Kinetics of tracheid development explain conifer tree-ring structure. New Phytol. 203, 1231-1241, http://dx.doi.org/10.1111/nph.12871.

de Luis, M., Novak, K., Raventós, J., Gričar, J., Prislan, P., Cufar, K., 2011a. Cambial activity, wood formation and sapling survival of Pinus halepensis exposed to different irrigation regimes. For. Ecol. Manage. 262, 1630-1638, http://dx.doi. org/10.1016/j.foreco.2011.07.013.

de Luis, M., Novak, K., Raventós, J., Gričar, J., Prislan, P., Čufar, K., Raventos, J., 2011b. Climate factors promoting intra-annual density fluctuations in Aleppo pine (Pinus halepensis) from semiarid sites. Dendrochronologia 29, 163-169, http://dx.doi.org/10.1016/j.dendro.2011.01.005.

De Micco, V., Campelo, F., de Luis, M., Bräuning, A., Grabner, M., Battipaglia, G., Cherubini, P., 2016. Intra-annual density fluctuations in tree rings: how, when, where and why? IAWA J. 37, 232-259, http://dx.doi.org/10.1163/2294193220160132.

Denne, M., 1988. Definition of latewood according to Mork. Iawa Bull 10, 59-62, http://dx.doi.org/10.1163/22941932-90001112.

Eilmann, B., Zweifel, R., Buchmann, N., Pannatier, E.G., Rigling, A., 2011. Drought alters timing, quantity, and quality of wood formation in Scots pine. J. Exp. Bot. 62, 2763-2771, http://dx.doi.org/10.1093/jxb/erq443.

Ferreira, O., Torrinha, A.M., Cardoso, P.M., 2010. Plano De Gestão Florestal: Mata Do Urso E Mata Nacional Do Pedrogão.

Gričar, J., Cufar, K., Oven, P., Schmitt, U., 2005. Differentiation of terminal latewood tracheids in silver fir trees during autumn. Ann. Bot. 95, 959-965, http://dx.doi. org/10.1093/aob/mci112.

Hacke, U.G., Sperry, J.S., Pockman, W.T., Davis, S.D., McCulloh, K.a., 2001. Trends in wood density and structure are linked to prevention of xylem implosion by negative pressure. Oecologia 126, 457-461, http://dx.doi.org/10.1007/ s004420100628.

IPCC, 2013. Climate change 2013: the physical science basis. contribution of working group I to the fifth assessment report of the intergovernmental panel on climate change. In: Intergov. Panel Clim. Chang. Work. Gr. I Contrib. to IPCC Fifth Assess. Rep. (AR5), Cambridge Univ Press. New York, p. 1535, http://dx. doi.org/10.1029/2000JD000115.

Jyske, T., Holtta, T., Mäkinen, H., Nojd, P., Lumme, I., Spiecker, H., 2010. The effect of artificially induced drought on radial increment and wood properties of Norway spruce. Tree Physiol. 30, 103-115, http://dx.doi.org/10.1093/treephys/ tpp099.

Kutschera, U., Niklas, K.J., 2013. Cell division and turgor-driven stem elongation in juvenile plants: a synthesis. Plant Sci. 207, 45-56, http://dx.doi.org/10.1016/j. plantsci.2013.02.004.
Loustau, D., Berbigier, P., Roumagnac, P., Arruda-Pacheco, C., David, J.S.S., Ferreira, M.I.I., Pereira, J.S., Tavares, R., Roumagnac, P., 1996. Transpiration of a 64-year-old maritime pine stand in Portugal.1. Seasonal course of water flux through maritime pine. Oecologia 107, 33-42, http://dx.doi.org/10.1007/ BF00582233.

Lupi, C., Morin, H., Deslauriers, A., Rossi, S., 2010. Xylem phenology and wood production: resolving the chicken-or-egg dilemma. Plant Cell Environ. 33, 1721-1730, http://dx.doi.org/10.1111/j.1365-3040.2010.02176.x.

Lupi, C., Rossi, S., Vieira, J., Morin, H., Deslauriers, A., Tognetti, R., 2014. Assessment of xylem phenology: a first attempt to verify its accuracy and precision. Tree Physiol. 34, 87-93, http://dx.doi.org/10.1093/treephys/tpt108.

Martínez-Vilalta, J., López, B.C., Loepfe, L., Lloret, F., 2012. Stand- and tree-level determinants of the drought response of Scots pine radial growth. Oecologia 168, 877-888, http://dx.doi.org/10.1007/s00442-011-2132-8.

McDowell, N., Allen, C.D., 2015. Darcy's law predicts widespread forest mortality under climate warming. Nat. Clim. Change 5, 669-672, http://dx.doi.org/10. 1038/nclimate2641.

Novak, K., de Luis, M., Raventós, J., Čufar, K., 2013. Climatic signals in tree-ring widths and wood structure of Pinus halepensis in contrasted environmental conditions. Trees - Struct. Funct. 27, 927-936, http://dx.doi.org/10.1007/ s00468-013-0845-5.

Olano, J.M., Eugenio, M., García-Cervigón, A.I., Folch, M., Rozas, V., 2012. Quantitative tracheid anatomy reveals a complex environmental control of wood structure in continental mediterranean climate. Int. J. Plant Sci. 173, 137-149, http://dx.doi.org/10.1086/663165.

Oribe, Y., Funada, R., Kubo, T., 2003. Relationships between cambial activity, cell differentiation and the localization of starch in storage tissues around the cambium in locally heated stems of Abies sachalinensis (Schmidt) Masters. Trees 17, 185-192, http://dx.doi.org/10.1007/s00468-002-0231-1.

Pacheco, A., Camarero, J.J., Carrer, M., 2015. Linking wood anatomy and xylogenesis allows pinpointing climate and drought influences on growth of coexisting conifers in continental Mediterranean climate. Tree Physiol. 36, 1-11, http:// dx.doi.org/10.1093/treephys/tpv125.

Pangle, R.E., Hill, J.P., Plaut a, J., Yepez a, E., Elliot, J.R., Gehres, N., McDowell, N., Pockman, W.T., 2012. Methodology and performance of a rainfall manipulation experiment in a ppiñon-juniper woodland. Ecosphere 3, art28, http://dx.doi org/10.1890/ES11-00369.1.

Pereira, J.S., 2002. Pinus Pinaster,In: Pinus of Silvicultural Importance. CABI Publishing, New York, pp. 316-328.

Pinheiro, J., Bates, D., DebRoy, S., Sarkar, D., Team, R.C., 2016. Nlme: Linear and Nonlinear Mixed Effects Models

Pittermann, J., Sperry, J.S., Wheeler, J.K., Hacke, U.G., Sikkema, E.H., 2006. Mechanical reinforcement of tracheids compromises the hydraulic efficiency of conifer xylem. Plant Cell Environ. 29, 1618-1628, http://dx.doi.org/10.1111/ j.1365-3040.2006.01539.x.

R Development Core Team, 2009. R: A Language and Environment for Statistical Computing. R Foundation for Statistical Computing, Vienna, Austria. ISBN 3900051-07-0, http://www.R-project.org.

Rossi, S., Anfodillo, T., Menardi, R., 2006. Trephor: a new tool for sampling microcores from tree stems. Iawa J. 27, 89-97.

Rossi, S., Morin, H., Deslauriers, A., 2012. Causes and correlations in cambium phenology: towards an integrated framework of xylogenesis. J. Exp. Bot. 63, 2117-2126, http://dx.doi.org/10.1093/jxb/err423.

Rozas, V., Garcia-Gonzalez, I., Zas, R., 2011. Climatic control of intra-annual wood density fluctuations of Pinus pinaster in NW Spain. Trees-Struct. Funct. 25, 443-453, http://dx.doi.org/10.1007/s00468-010-0519-5.

Sarris, D., Christodoulakis, D., Korner, C., 2007. Recent decline in precipitation and tree growth in the eastern Mediterranean. Glob. Change Biol. 13, 1187-1200.

Steppe, K., Sterck, F., Deslauriers, A., 2015. Diel growth dynamics in tree stems: linking anatomy and ecophysiology. Trends Plant Sci. 20, 335-343, http://dx doi.org/10.1016/j.tplants.2015.03.015.

Vieira, J., Campelo, F., Nabais, C., 2009. Age-dependent responses of tree-ring growth and intra-annual density fluctuations of Pinus pinaster to Mediterranean climate. Trees - Struct. Funct. 23, 257-265, http://dx.doi.org/ 10.1007/s00468-008-0273-0.

Vieira, J., Campelo, F., Nabais, C., 2010. Intra-annual density fluctuations of Pinus pinaster are a record of climatic changes in the western Mediterranean region. Can. J. For. Res. 40, 1567-1575, http://dx.doi.org/10.1139/X10-096.

Vieira, J., Rossi, S., Campelo, F., Nabais, C., 2014. Are neighboring trees in tune? Wood formation in Pinus pinaster. Eur. J. For. Res. 133, 41-50, http://dx.doi.org/ 10.1007/s10342-013-0734-X.

Vieira, J., Campelo, F., Rossi, S., Carvalho, A., Freitas, H., Nabais, C., 2015. Adjustment capacity of maritime pine cambial activity in drought-prone environments. PLoS One 10,1-15, http://dx.doi.org/10.1371/journal.pone.0126223.

Wood, S.N., 2006. Generalized Additive Models: An Introduction with R. Boca Rantom, http://dx.doi.org/10.1111/j.1541-0420.2007.00905_3.x.

Zalloni, E., Luis, M., De Campelo, F., Novak, K., Micco, V., De Filippo, A., Di Vieira, J., Nabais, C., Rozas, V., Battipaglia, G., 2016. Climatic signals from intra-annual density fluctuations frequency in Mediterranean Pines at a regional scale. Front. Plant Sci. 7, 1-11, http://dx.doi.org/10.3389/fpls.2016.00579. 